\title{
Augustan triumphal iconography and the Cantabrian Wars: Some remarks on round shields and spearheads depicted on monuments from the Iberian Peninsula and Italy*
}

\section{Iconografía triunfal augustea y las guerras cántabras: algunas observaciones sobre escudos redondos y puntas de lanza representados en monumentos de la Península Ibérica e Italia}

\author{
Eugenio Polito \\ Università degli Studi di Cassino
}

\begin{abstract}
SUMMARY
Depicted arms and armour became particularly widespread in the Augustan period, when the Prince's veterans tended to emphasise their role in the consolidation of the Empire with the adoption of these war themes in their tombs. The comparison between some funerary reliefs from Italy, the so-called Lusitanian Warriors, and some monetary emissions from the Iberian Peninsula, together with a recent finding in the Forum of Augustus, allows for the hypothesis that the celebration of Augustan victories in this region could have significantly contributed to the repertoire of depicted weapons that celebrated the new Empire.
\end{abstract}

\section{RESUMEN}

Las armas representadas en bajorelieve fueron particularmente generalizadas en la época de Augusto, cuando los veteranos del príncipe tendido a enfatizar su importancia en la consolidación del imperio con la adopción de estos temas de guerra en sus tumbas. La comparación entre algunos relieves funerarios de Italia, los llamados guerreros lusitanos, y algunas de las emisiones monetarias de la Península Ibérica, junto con un reciente hallazgo desde el Foro de Augusto, permiten plantear la hipótesis de que la celebración de las victorias de Augusto en esta región podría tener significativamente contribuido al repertorio de las armas representadas que celebraban el nuevo Imperio.

KEY WORDS: Augustan age, Forum Augustum, Roman Spain, Roman relief sculpture, Roman coinage in Spain, IberianCeltiberian Weapons, Lusitanian Warriors.

* I wish to thank Isabel Rodà de Llanza, Cinzia Vismara and the two anonymous reviewers for their helpful criticism; further Andrea Coletta, Thierry Lejars, Roberto Meneghini, Maria Cristina Molinari, Francesca Morandini, Beatrice Pinna Caboni, Filli Rossi, Francesco Sirano, and Stefania Tuccinardi for their kind help in different issues regarding this paper.
PALABRAS CLAVE: Época augustea, Foro de Augusto, Guerras cántabras, España romana, Escultura de relieve romana, Acuñación de monedas romanas en España, Armas íbero-celtíberas, Guerreros lusitanos.

The iconography of stacked arms and armour, together with those isolated in the metopes of the Doric friezes, characterises a large number of funerary monuments erected by the first generations of Augustan followers in Italy (Polito 1998; 2011, with lit.). The extraordinary popularity enjoyed at this stage by this artistic subject among Augustan veterans and settlers cannot be explained without assuming highlevel urban models. Nevertheless, the search for examples related to official monuments of this period is not generous with its results. The celebration of the Actium victory of $31 \mathrm{BC}$ in Rome seems to be recalled in an important series of reliefs pertaining to an unknown urban monument, in which the depicted objects are not weapons, but instead parts of ships and sacrificial instruments (Hölscher 1985: 84-87 figs. 1-2; Leoncini 1987), a choice that has perhaps to be explained by the desire not to emphasise the bloody aspect of the epilogue of the Civil Wars, which rather required forms of expiation. However, the impact of the commemorative monument of Nicopolis, which contained a frieze with weapons, is yet to be fully assessed (Zachos 2003: 83-85 figs. 28, 30-31; 2007: I, 418 and passim; II, 311 drawing 6; 315 figs. 8-9). It cannot, therefore, be excluded that the ship spoils, which appear frequently in funerary monuments, rest on models created in relation to the Actium victory. 


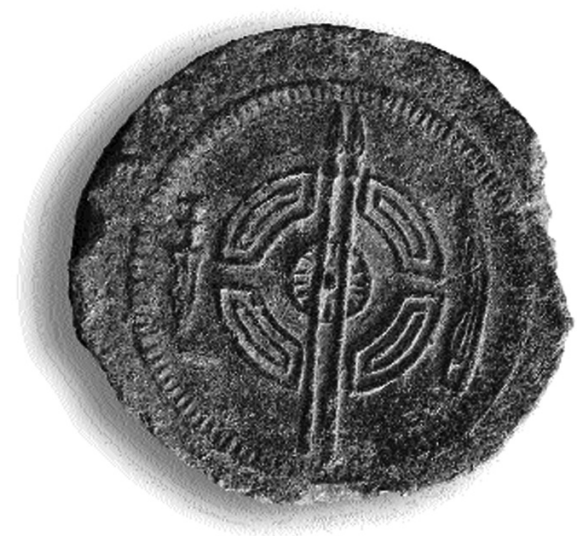

Figura 1. AE Dupondius. Mint of Northwestern Spain, probably Lugo, after 27 BC. D.: 30,4-29,8 mm.; 18,8 g. Obv.: IMP AVG DIVI F. Head of Augustus 1. between palm and caduceus. Rev.: Round shield with labyrinth pattern crossed by two spears or javelins, between celtiberian bi-discoidal pugio and falcata. RPC I, 1992, 2 (Lugo, Sala de Exposicións Porta Miña. Ayuntamiento de Lugo, Inv. SD.6).

The celebration of the signa recepta after $20 \mathrm{BC}$, following the restitution of the Roman standards caught by Parthians from Crassus' legions in the Carrhae defeat of $53 \mathrm{BC}$, has been convincingly connected to a small group of urban reliefs with weapons, also from an unknown monument, containing an explicit reference to the Eastern world in the depiction of the Parthian tiara (Tempesta 1991/92: 323 figs. 8-9).

Nevertheless, the weapons depicted in the many funerary monuments of the Augustan period show a very diverse repertoire, with many types related to the barbaric West, whose presence cannot be justified only with reference to any monuments celebrating the victory of Actium, or the return of Crassus' standards. The variety of references to the entire universe of the enemies of Rome suggests the presence of a substrate prepared for a long time, possibly going back to Republican monuments, if not to earlier Hellenistic specimens (examples collected in Polito 1998): the most prominent and already in some sense universal examples are the weapon friezes from the sanctuary of Athena at Pergamon, but it is difficult not to consider the Republican coinage, frequently depicting trophies.

The conventional aspect of many decorations must not discourage us: under the veil of an often repetitive artistic language and the poor quality of many funerary ornaments of the early Empire, one can still try to distinguish conventional elements from specific types of weapons. Important clues suggest, for example, that a significant role in the formation of the

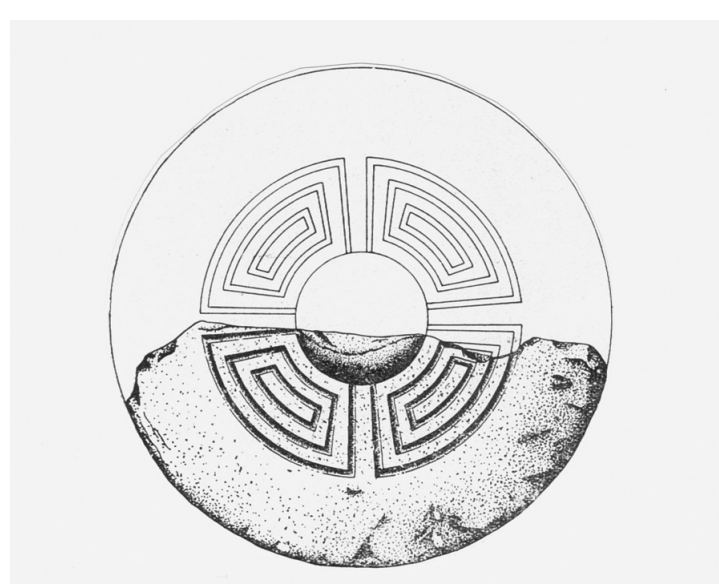

Figura 2. Graphic reconstruction of the shield worn by a Warrior Statue from Cendufe (Portugal). Lisboa, Museu Nacional de Arqueologia (from Cabré Aguiló 1940, pl. XVII, 1).

weapons-repertoire may have been played by the Cantabrian and Asturian Wars (29-19 BC) (on the Cantabrian Wars see Almagro Gorbea 1999; Rodà 2006, with prev. literature). Some types of weapons carved in early imperial reliefs are in fact unmistakably linked to the Iberian world.

This is particularly evident in the case of labyrinth-patterned round shields depicted on coins related to the wars that took place in the Iberian Peninsula in the early Augustan period (Fig. 1) (RPC I, 1992, 67-68 nr. 1-4 pl. I, 1-4; RPC Suppl. I, 1998, p. 7 with lit.), but also carried by the so-called Lusitanian warrior-statues from Portuguese Galicia (Fig. 2) (Calo Lourido 1994; Quesada Sanz 2003; Die lusitanischgalläkischen Kriegerstatuen 2003,nr. 8, p. 9 pls. 67): the shield type has been recognised in the caet$r a$ of the Iron Age Hispanic populations (Cabré Aguiló 1939-40; see also Guadán 1979; Quesada Sanz 1997: 489-532). The comparison with weapon friezes from early Imperial grave monuments is striking: a Doric frieze from Rome (Fig. 3) (Mustilli 1938: 186 nr. 104 pl. CXVII, 454; Blanco Freijeiro 1971: 231 pl. II fig. 2), dated as the whole group no later than the first decades of the power of Augustus, and a relief-plate with a flat frame from Pietrabbondante Samnitic sanctuary (Fig. 4) (Colonna 1974: pl. XCVIIIa; Cianfarani et alii 1978: 484 pl. 310; Italia dei Sanniti 2000: 46 fig. 55), show exactly this type of shield, with the same labyrinth pattern. For the latter, the 2 nd century BC dating proposed in previous editions should be rejected; in our opinion it was part of the decoration of a sepulchral monu- 


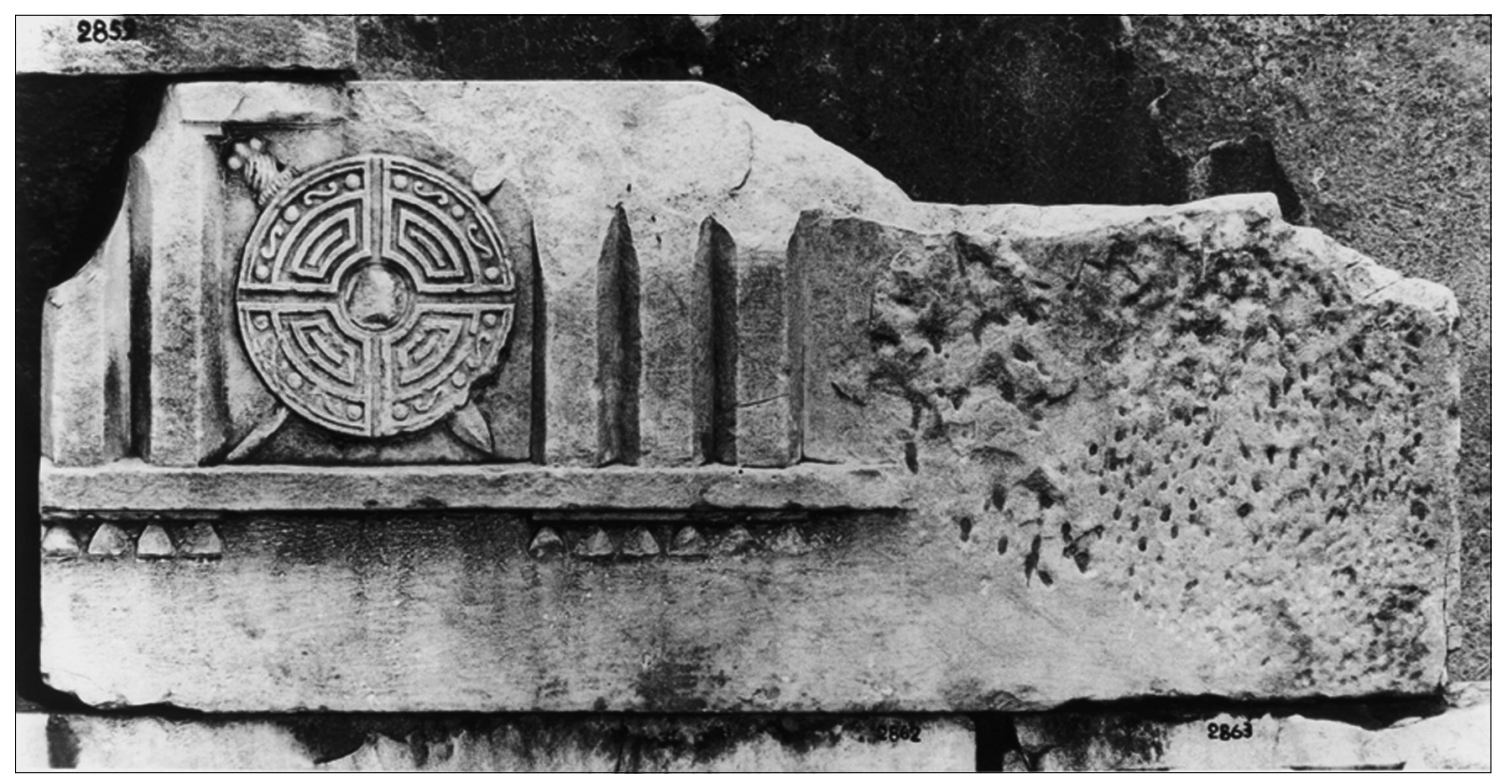

Figura 3. Doric frieze from Porta Flaminia. Rome, Musei Capitolini, Giardino Caffarelli (DAI Rom Inst. Neg. 29.141).

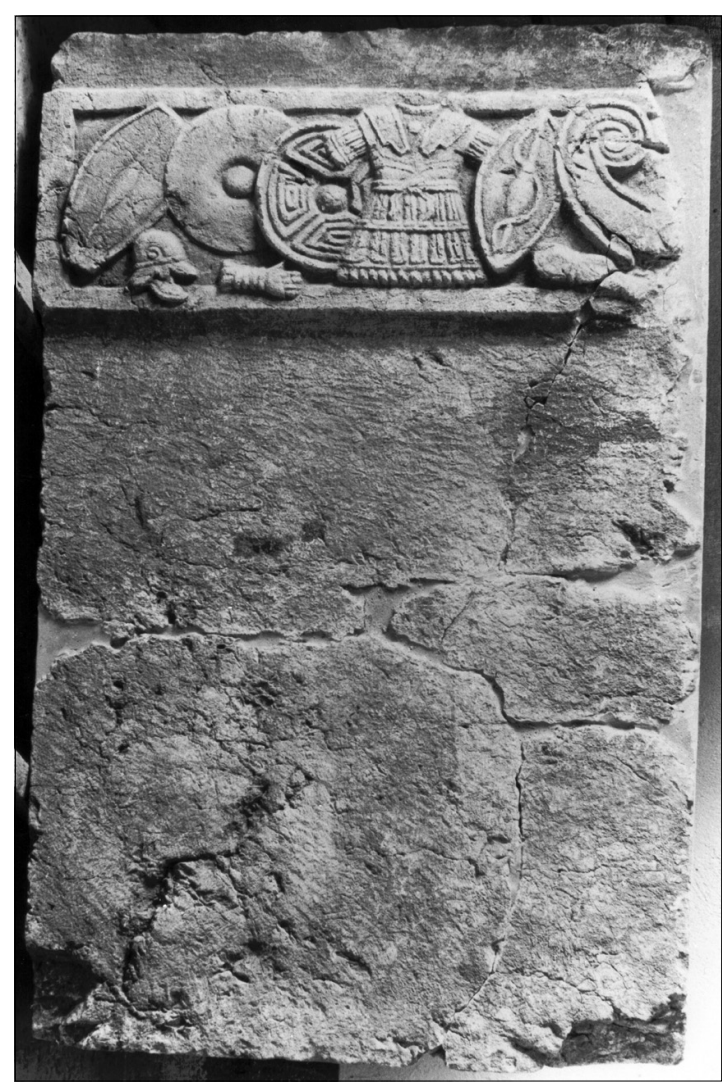

Figura 4. Relief slab from Pietrabbondante (Molise, Italy) (DAI Rom Inst. Neg. 75.2648).

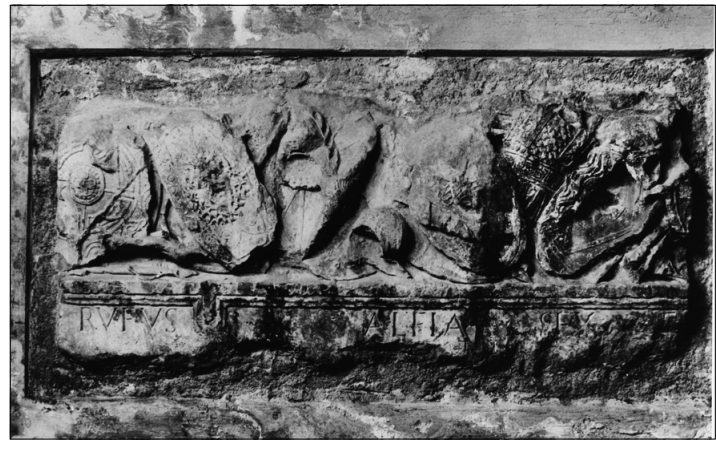

Figura 5. Relief plate from Trasacco in the Marsica region (Abruzzo, Italy). Trasacco (AQ), Oratorio di S. Cesidio (DAI Rom Inst. Neg. 79.2736).

ment erected in the cemetery planted in the area of the samnite sanctuary after the Social War, so probably between the end of the Republic and the early Augustan age. Among various considerations, the comparison with the mentioned coins and monuments has its weight.

Even if the depictions of the labyrinth-caetra on monuments from ancient Callaecia could allow a reference to earlier times, such as the conquest of this region by Brutus Callaicus, who celebrated his triumph in $136 \mathrm{BC}$, the Augustan dating of the above mentioned coins suggests an Augustan chronology also for the creation of the iconography. Significantly, 


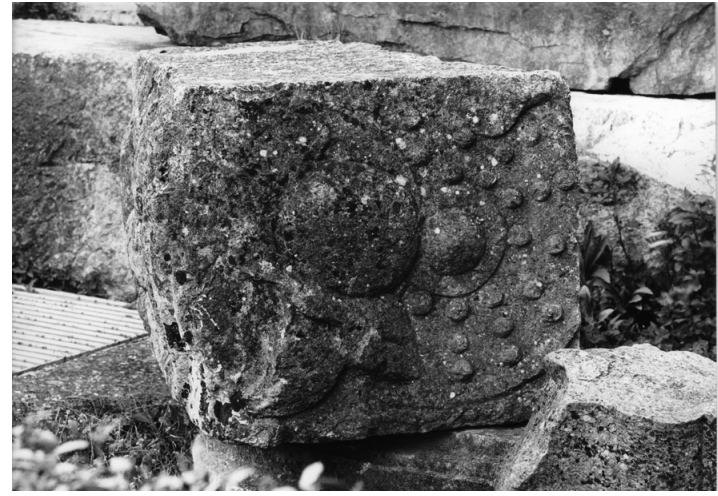

Figura 6. Tufa stone block with depiction of weapons. S. Maria Capua Vetere (Caserta, Italy) formerly in the Amphitheatre area (DAI Rom Inst. Neg. 1026 VW 84).
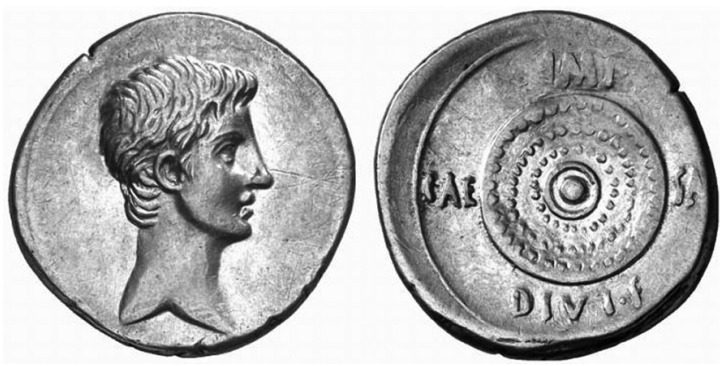

Figura 7. AR Denarius. Uncertain mint (Spain), 27-26 BC; D. $20 \mathrm{~mm}$; 3,86 g. Obv.: head of Octavian r. Rev.: IMP / CAE $\mathrm{SA}[\mathrm{R}]$ / DIVI F. - Shield with three rows of concentric studs. RIC I², 1984, 543a (Numismatik Lanz München - Auktion 132 - November 27, 2006 - Lot Nr. 324).

another example is depicted in a frieze from a monument of Trasacco in ancient Marsica (Abruzzo, Italy), related to a prominent family of equestrian rank in the area and now convincingly dated to the late Augustan or early Tiberian period (Fig. 5) (Strazzulla 2007).The labyrinth shield is well attested in later times, however, as for instance in an important and neglected frieze from Split (Polito 1998: 155 f. fig. 89 ) and in the reliefs from Trajan's Forum (Meneghini 2001: fig. 5; Ungaro 2002: 128 fig. 1).

A similar case is that of a frieze block from ancient Capua (Fig. 6) (formerly in the garden in front of the Amphitheater of Santa Maria Capua Vetere, unpublished), showing a circular shield with concentric rows of studs, which closely resembles denarii probably struck in the Iberian peninsula during the Augustan wars (Fig. 7) (RIC I ${ }^{2}, 1984,38 ; 85$ nr. 543 $\mathrm{a}-\mathrm{b}, \mathrm{pl}$. 10). As in the case of the labyrinth shield, it was supposed to reproduce an indigenous shield,

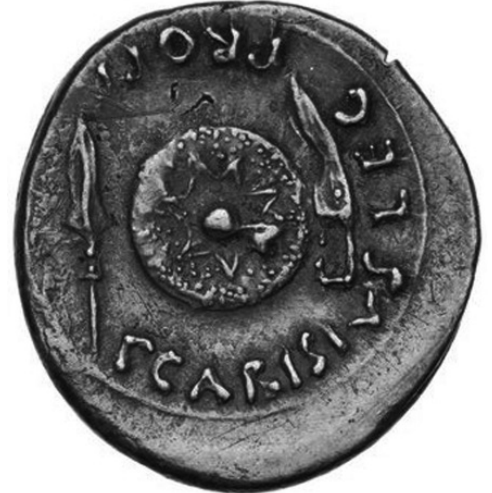

Fig. 8. AR Denarius. Emerita, ca. 25-23 BC. 3.35 g. Obv.: IMP CAESAR AVGVST. Head of Augustus to r. Rev.: P CARISIVS LEG PRO PR - Shield with lozenge pattern and studs between spear and falcata. RIC $\mathrm{I}^{2}, 1984,2$ a (American Numismatic Society 1944.100.39019).
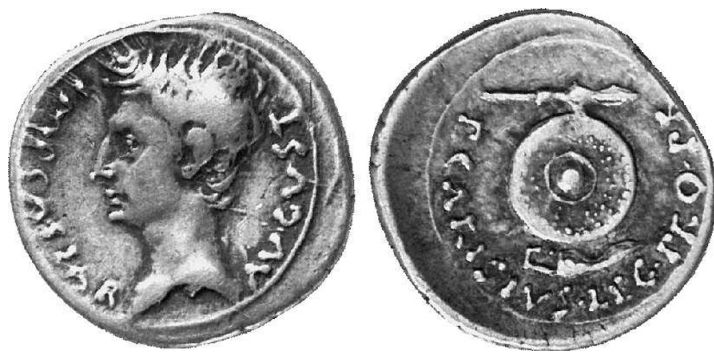

Figura 9. AR Denarius, Emerita, ca. 25-23 BC. D.: $20 \mathrm{~mm}$; 4.03 g. Obv.: IMP CAESAR AVGVST. Head to 1. Rev.: P CARISIVS LEG PRO PR. Shield with studs between spear and falcata. Cohen 1880, 401; Giard 2001, 1033 (Numismatik Lanz München - Auktion 94 - November 22nd, 1999, Lot Nr. 35).

which was also very likely linked to the Roman victories in the Iberian Northwest. This emission is strictly related to another, better known coin series signed by P. Carisius, legatus in Spain in this period, which shows a circular shield decorated with a lozengepattern and studs flanked by an Iberian falcata and a long triangular spearhead with concave blades (Fig. 8) (RIC $I^{2}, 41 \mathrm{nr} .2 \mathrm{a}-\mathrm{b}, \mathrm{pl}$. 1). The relationship between these two series is attested by a rarer variant coin of the Carisius emission, in which the lozengeshield is substituted by the one with concentric rows of studs (Fig. 9) (Cohen 1880, 401; Giard 2001: 1033).

The Carisius emissions also include other series with triumphal subjects that have been convincingly compared with the so-called "Triumphalprägung" of Octavian (Trillmich 1990: 300-302; García-Bellido 2008: 193-195). The whole coin group has been the subject of a long scholarly discussion, involving 
the mint identification and other issues impossible to discuss here (García-Bellido 2004: 78, with lit.). Here, we will not deal with other significant weapons and pieces of armour depicted on the same coins and on other related emissions, such as the above mentioned struck with the caetra: the falcata (figs. 1, 8, 9 right), which was apparently not depicted on weapon friezes; the Celtiberian bidiscoidal pugio (fig. 1, left), which is difficult to distinguish from other similar short glaives on such friezes; and, finally, a singular maskhelmet, whose depiction on another emission of the same series has been the subject of an interesting hypothesis that would require a separate discussion (RIC I² 1984, 8; García-Bellido 2004: 80, with discussion). Nevertheless, without doubt such war symbols may be traced to an earlier tradition in the history of the ancient Iberian region: one should compare an emission of Turrirecina (Badajoz), probably dating to the 2nd Century BC and featuring the caetra with the falcata (García-Bellido and Blázquez 2001: II, 383, nr. 1). If the Turrirecina-coins are to be interpreted as symbols of local identity, so the latter emission has also to be seen as a tribute and not simply a trophy (as in other Carisius coins), in gratitude for the already completed conquest: a comparison has been suggested with the iconographic pattern of the Augustan clipeus virtutis (García-Bellido 2008: 193195, with broader discussion).

However, at least another weapon type depicted on such coins provides an argument in favour of the connection between Italian veteran monuments and the Roman victories in Spain: it is the long spearhead with concave blades, which occurs in the above discussed emissions (figs. 8-9, left), as well as in weapon friezes within the same period. A Padua frieze is well-

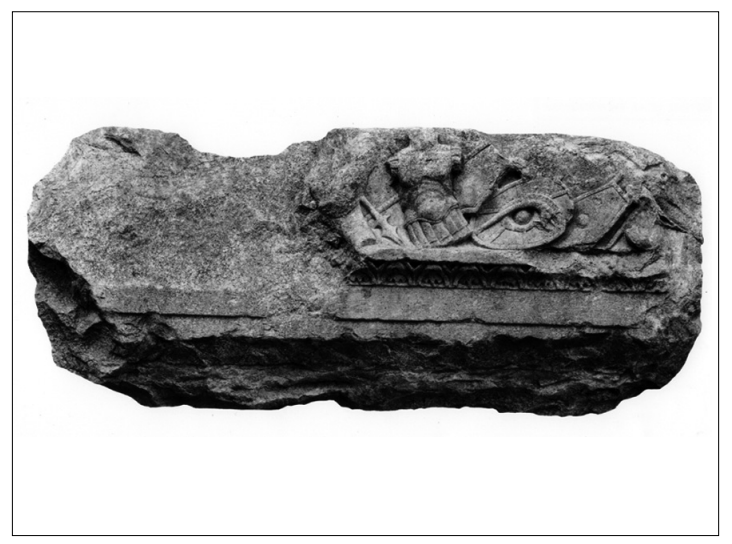

Figura 10. Frieze block from Padua. Padova, Italy, Museo Civico, Catalogo delle Collezioni Lapidarie I, $\mathrm{n}^{\circ} .150$ (Photo Courtesy of Musei Civici, Padua, Neg. nr.14416). dated to the Augustan period on the basis of the annexed moulding (Fig. 10) (Polito 1998: 169 fig. 111). More difficult to place chronologically, though probably dating back to the same period (or slightly later), is a frieze of rather rough quality, but with interesting antiquarian details, pertaining to a funerary monument and now walled in Piazza della Loggia in Brescia (Fig. 11) (unpublished; see Passamani 1979: 34 ), in which the spears are associated a square-patterned shield that could be the result of a distortion of the labyrinth-pattern.

Apparently, there is no exactly comparable specimen among preserved spearheads from the Late Iron Age Iberian peninsula: considering the weapons depicted on the Carisius emission, the Spanish scholar Fernando Quesada Sanz came to the conclusion that: “... las armas representadas no son necesariamente las armas cántabras, sino la idea o prototipo de arma bárbara y exótica, tomada de la panoplia hispana que los Romanos conocían de antemano ( $\mathrm{fal}$ cata por ejemplo)" (Quesada Sanz 1997: 421 with Pl. XVA). In fact, similar spearheads from the Caesarian battlefield of Alesia in Gaul have been ascribed to the Roman army on the base of a very feeble hypothesis (Sievers 2001, 161, $224 \mathrm{sg}$. nr 270-278; 180 fig. 13; pl. 62, particularly nr. 274-276). One should also remember that Caesar used, among others, units of Hispanic cavalry, and that similar weapons are depicted on the Mausoleum of the Iulii in St. Remyde-Provence (Couissin 1923: 311 fig. 3; Rolland 1969: 63 Pls. 27, 31, 42).

Nevertheless, it is beyond doubt that, from the Roman point of view, the panoply on the above discussed emissions recalled a specific Hispanic horizon, which cannot be identified, at this historical

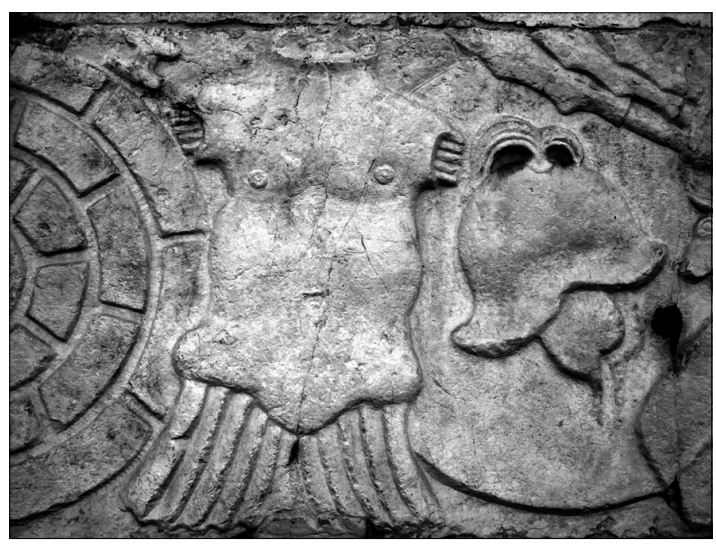

Figura 11. Frieze plate walled in the façade of the Monte di Pietà in Piazza della Loggia, Brescia, Italy (Photo Stefano Bolognini, Milan). 


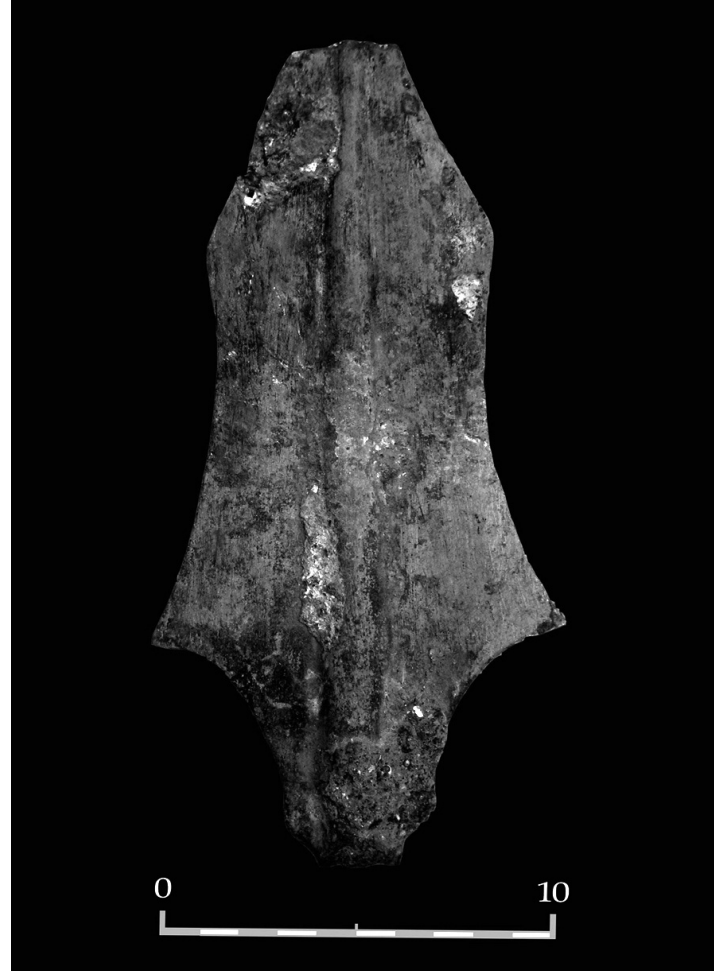

Figura 12. Spearhead from recent excavations in Augustus' Forum, Rome (Archivio Fotografico Ufficio Scavi Fori Imperiali, Roma - Photo Beatrice Pinna Caboni).

moment, but with the north-western region in which most military operations took place. That this specific type of spearhead cannot be compared with real findings of the area should not be taken as proof against this theory. Together with caetra, falcata, pugio and possibly other weapons, it could have been taken as a symbol of the victories over Cantabri and Astures, thanks also to the typical inexactitude of ancient Ethnology, that, for instance, allowed a Gallic trumpet (carnyx) to be depicted on a trophy of another Carisius emission, in a perspective that saw perhaps the Cantabri as "relatives" of the Gauls (Trillmich 1990, 300). It is a fact, however, that the discussed spearheads do not appear in other more typical Celtic or otherwise "barbarian" iconographies, and that the only reliable path leads to the Carisius emissions.

A new archaeological find from the Forum of Augustus could be eventually connected to this spear type and represent a key to the overall reading of the iconography thus far reported. Indeed, a spearhead with concave blades has come to light during recent excavations (Fig. 12) (Coletta \& Pinna Caboni 2010: 73-74 fig. 26). It is the opinion of the publishers that

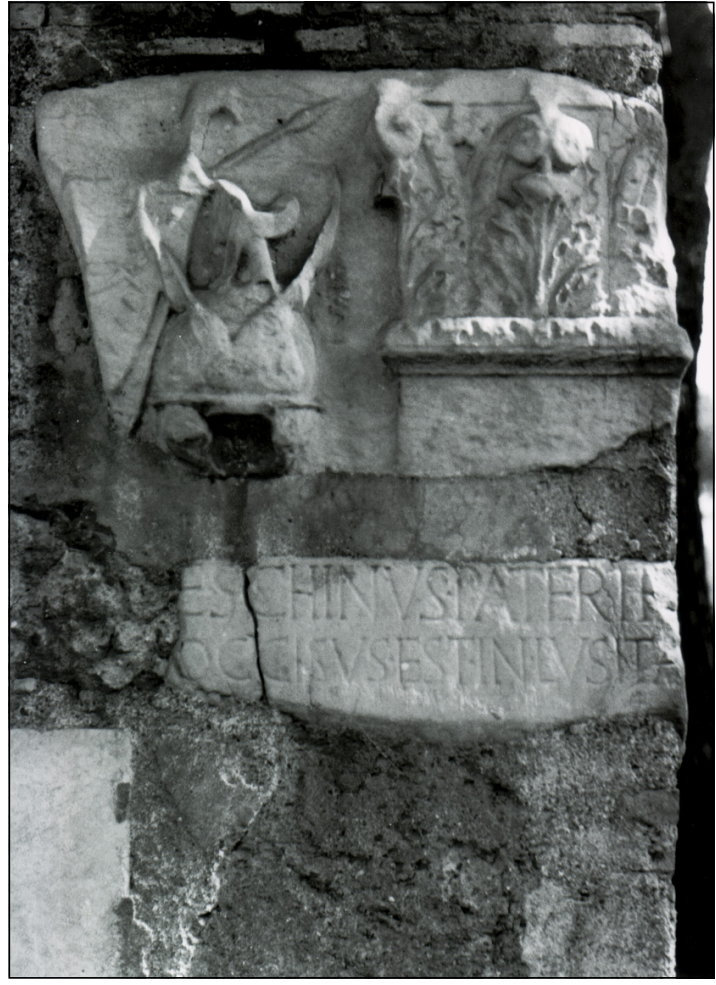

Figura 13. Fragments of frieze and inscription walled in the Tomba dei Rabirii on the Via Appia in Rome (IV Mile) (Author's Photo).

the spearhead was part of an artistic decoration statue or trophy - rather than a real weapon. The reference to the iconography of the weapon friezes is convincing: the publishers follow the iconographic fortune of this spear type until the panoplies of the Hadrianeum in Rome (Coletta \& Pinna Caboni 2010: 74 note 39 ).

As far as Augustus's Forum is concerned, it is difficult not to refer to a famous Ovid passage, which alludes to arms, perhaps represented, at the entrance either of Augustus' Forum or of the Temple of Mars Ultor Fasti 5, 561 f.: "Perspicit (scil. Mars) in foribus diversae tela figurae / armaque terrarum milite victa suo"; cp. Zanker 1968: 12). The Forum of Augustus became in fact the central place of imperial war policy, in which individual generals were required to deposit their weapons booty (Suet. Aug. 29; Cass. Dio 55, 10, $2 \mathrm{~s}$.). It is no surprise that the repertoire of war symbols created in the aftermath of the last major military campaigns that involved the same Augustus, namely the Cantabrian Wars, was recalled later in the decoration of the Forum of Augustus, which opened in $2 \mathrm{BC}$. 
The preserved documents and monuments hardly allow going beyond this point. We would wish to know more about a frieze fragment with weapons from a funerary monument of the Via Appia in Rome, which is preserved in the tomb of the Rabirii, with an inscription that mentions a military tribune who died in Lusitania (Fig. 13) (CIL, VI 3502; Polito 1998: 162 fig. 98); Ricci 2006: 121 fig. 29 : - - - - - ?/[- - A]eschinus pater, tr(ibunus) [militum - - -?], / occisus est in Lusit[ania - - - / - - - - - ?).: the association between the frieze fragment and the inscription is quite likely considering the type of marble, apparently identical, and the similar chronology of both in the Augustan age. We would not be surprised to discover that the monument iconography eventually included a reference to the wars fought in the Iberian Peninsula at that time.

In conclusion, it is plausible that in the early Augustan age one or more commemorative monuments contained references to the Augustan wars in the Iberian Peninsula, the importance of which has been increasingly stressed in recent research (Morillo Cerdán 2002; Pérez-González and Illarregui 2005; Morillo Cerdán 2006; Morillo Cerdán and Aurrecoechea 2006; García-Bellido 2006). The existence of an Augustan triumphal monument for the bellum Cantabrum, possibly echoing an older monument for the Cimbric victory of Marius, has been argued by W. Trillmich based on the comparison of the Carisius emissions with coins struck about 100 BC (Trillmich 1990: $300 \mathrm{f}$.). The celebration of such a victory would have allowed Augustus to put a Western victory beside the Oriental victory over Antonius - so becoming the peace bringer of the oecumene - and also to underline a victory in a bellum externum, so overshadowing the recently ended bellum civile. It should be pointed out that the lost autobiography of Augustus was interrupted significantly in $26 \mathrm{BC}$, coinciding with the last military campaign conducted personally by the prince. By then, the direct relationship between Octavian's veterans and their leader came to an end (Rich 2009). For the first generations of soldiers loyal to the prince, it was probably easier to refer to the decade-long wars in Spain, with whose celebratory themes they could best identify, rather than to the Actian war. After some eventual Hellenistic examples, and perhaps some unknown late-republican monuments, it is likely, therefore, that the models created at this stage helped to form the basis of the standard repertoire of weapons of the vanquished, so often repeated in many different contexts until late antiquity.

\section{BIBLIOGRAPHY}

Almagro Gorbea, M. et alii 1999: Las Guerras Cántabras, Santander.

Blanco Freijeiro, A. 1971: "Monumentos romanos de la conquista de Galicia", Habis 2, 223- 232.

Cabré Aguiló, J. 1939-40: "La caetra y el scutum en Hispania durante la Segunda Edad del Hierro", Boletín del Seminario de Estudios de Arte y Arqueología 6, 57-83.

Calo Lourido, F. 1994: A plaistica da cultura castrexa galego-portuguesa, La Coruña.

Cianfarani, V.; Franchi Dell'Orto, L. and La Regina, A. 1978: Culture adriatiche di Abruzzo e di Molise, Roma.

Cohen, H. 1880 : Description historique des monnaies frappées sous l'Empire romain, Paris-London.

Coletta, A. and Pinna Caboni, B. 2010: "Gli elementi architettonici dallo scavo del Foro di Augusto", R. Meneghini \& R. Santangeli Valenzani (eds.), Scavi dei Fori imperiali. Il Foro d'Augusto. L'area centrale, Roma, 63-75.

Couissin 1923: "Les guerriers et les armes sur les basreliefs du Mausolée des Jules à Saint- Remy", Revue Archéologique, 303-321.

Colonna, G. 1974: "Scavi e scoperte", Studi etruschi 42, 505-555.

Die lusitanisch-galläkischen Kriegerstatuen 2003: Die lusitanisch-galläkischen Kriegerstatue, Madrider Mitteilungen 44, XI-XX, 1-307.

García-Bellido, M. P. 2004: Las legiones hispánicas en Germania. Moneda y campamento, Anejos de Gladius 6, Madrid.

García-Bellido, M. P. 2006: Los campamentos romanos en Hispania (27 a.C.-192 d.C.): el abastecimiento de moneda, Anejos de Gladius 9, Madrid.

García-Bellido, M. P. 2008: "La representación iconográfica de Hispania e hispanos en la Roma republicana", E. La Rocca, P. León and C. Parisi Presicce (eds.), Le due patrie acquisite. Studi di archeologia dedicati a Walter Trillmich, Supplementi del Bullettino della Commissione Archeologica Comunale di Roma 18, Roma, 185-196.

García-Bellido, M. P. and Blázquez, C. 2001: Diccionario de cecas y pueblos hispánicos, Madrid.

Giard, J. B. 2001 : Bibliothèque nationale de France. Catalogue des monnaies de l'Empire romain, I. Auguste, Troisième édition, augmentée et mise à jour, Paris.

Guadán, A. M. 1979: Las armas en la moneda ibérica, Madrid.

Hölscher, T. 1985: "Denkmäler der Schlacht von Actium. Propaganda und Resonanz”, Klio 67, 81-102. 
Italia dei Sanniti 2000: Italia dei Sanniti. Guida alla mostra, Roma 2000, Milano.

Leoncini, L. 1987: "Frammenti con trofei navali e strumenti sacrificali dei Musei Capitolini. Nuova ipotesi ricostruttiva”, Xenia 13, 13-24.

Meneghini, R. 2001: "Il Foro di Traiano. Ricostruzione architettonica e analisi strutturale", Römische Mitteilungen 108, 245-268.

Morillo Cerdán, Á. 2002 (coord.): Arqueología militar romana en Hispania, Madrid.

Morillo Cerdán, Á. 2006 (ed.): Arqueología militar romana en Hispania II: producción y abastecimiento en el ámbito militar, León.

Morillo Cerdán, Á. and Aurrecoechea, J. 2006 (eds.): The Roman army in Hispania: an archaeological guide, León, 151-165.

Mustilli, D. 1938: Il Museo Mussolini, Roma.

Passamani, B. 1979: "La coscienza della romanità e gli studi antiquari tra Umanesimo e Neoclassicismo", Brescia romana. Materiali per un museo II, Brescia, 5-49.

Pérez-González, C. and Illarregui, E. 2005 (eds.): Arqueología militar romana en Europa. Roman military archaeology in Europe, Segovia.

Polito, E. 1998: Fulgentibus armis. Introduzione allo studio dei fregi d'armi antichi, Roma.

Polito, E. 2011: La pietrificazione delle armi conquistate, D. Loscalzo and C. Masseria (eds.), Miti di Guerra, riti di pace, Atti del Convegno, Bari, 259266.

Quesada Sanz, F. 1997: El armamento ibérico. Estudio tipológico, geográfico, funcional, social y simbólico de las armas en la Cultura Ibérica (s. VI-I a.C.), Montagnac.

Quesada Sanz, F. 2003: “Espejos de piedra? Las imágenes de armas en las estatuas de los guerreros llamados galaicos", Madrider Mitteilungen 44, 87-112.

RIC I'2, 1984: Roman Imperial Coinage, I. Revised Edition, London.

Ricci, C. 2006: Qui non riposa. Cenotafi antichi e moderni fra memoria e rappresentazione, Roma.

Rich, J. 2009: "Cantabrian closure: Augustus Spanish war and the ending of his memoirs", C. Smith and
A. Powell, (eds.), The lost memoirs of Augustus and the development of Roman autobiography, Swansea (Wales), Oxford, Oakville (CT), 145-172.

Rodà, I. 2006: "The Cantabrian wars and the reorganization of North Hispania: between literary sources, epigraphy and archaeology", A. Morillo Cerdán \& J. Aurrecoechea (eds.), The Roman army in Hispania: an archaeological guide, León, 53-63.

Rolland, H. 1969: Le Mausolée de Glanum (SaintRémy-de-Provence) (Gallia Suppl. XXI), Paris.

RPC I, 1992: Roman provincial coinage I, LondonParis.

RPC Suppl I, 1998: Roman provincial coinage, Suppl. I, London-Paris.

Sievers, S. 2001: "Les armes d'Alésia", Alésia. Fouilles et recherches franco-allemandes sur les travaux militaires romains autour du Mont-Auxois (1991-1997), vol. 2: Le matériel (Mémoires de l'Académie des Inscriptions et Belles Lettres), Paris, 121-291.

Strazzulla, M. J. 2007: “Dona et signa: un monumento funerario di militari a Trasacco", Fucino: studi sulla cultura figurativa, Bari, 57-132.

Tempesta, A. 1991/92: "I rilievi con armi Cesi: ipotesi di ricomposizione e di interpretazione", $\mathrm{Bu}$ llettino della Commissione Archeologica Comunale di Roma 94, 2, 309-340.

Ungaro, L. 2002, "I Daci dal Foro di Traiano", M. De Nuccio and L. Ungaro (eds.): I marmi colorati della Roma imperiale, Exhibition Cat. Rome 2002-2003, Roma, 128-133.

Zachos, K. L. 2003: "The tropaeum of the sea-battle of Actium at Nikopolis: interim report", Journal of Roman Archaeology 16, 65-92.

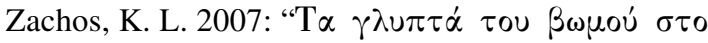

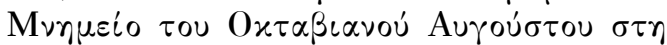

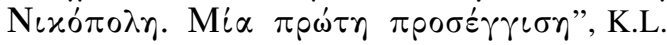

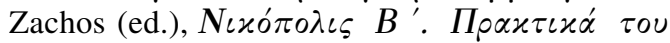

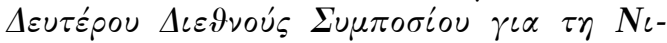

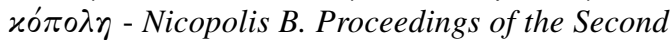
International Nicopolis Symposium Preveza 2002, Preveza, I, 411-434; II, 307-321.

Zanker, P. 1968: Forum Augustum. Das Bildprogramm, Tübingen. 